\title{
住民による管理活動が公園の犯罪不安感に与える影響 EFFECT OF ADOPT-A-PARK-PROGRAM WITH REGARD TO FEAR OF CRIME IN PARKS
}

\author{
樋野公宏*, 小出 治** \\ Kimihiro HINO and Osamu KOIDE
}

\begin{abstract}
The purpose of this study is to evaluate the effect of adopt-a-park-program on factors in fear of crime in parks and show how these factors are related to fear of crime. The analysis of the questionnaire shows that 17 of 18 factors picked up from complaints to Itabashi ward office significantly relate to fear of crime and that parks with adopt-program are significantly superior in $\mathbf{1 5}$ factors. It concludes that adopt-a-park-program contributes to sense of security in parks, since surveillance and territoriality in parks enhance it and correlate with litter in parks, which brings vandalism and undesirable acts.
\end{abstract}

Keywords : Fear of crime, Sense of security, CPTED, Broken windows theory, Adopt-a-park-program 犯罪不安(感)、安心感、防犯環境設計、割れ空理論、公園里親制度

1 はじめに

\section{1-1 研究の背景と目的}

公園は、地域コミュニティの場であり、緑のまちづくり、防災ま ちづくりの観点からも重要な公共施設である。しかし近年では、公 園における犯罪が増加しており、内閣府の「治安に関する世論調查 (2004)」でも犯罪に遭うかもしれない不安な場所として上位注1) なるなど、その存在が住民の不安要因となるケースさえ見られる。 また犯罪行為でなくても、公園施設への落書きや破壊行為、園内で の若者のたむろなども住民の不安要因となっていると考えられる。 防犯施策が進んだ英国では、犯罪及び秩序違反法 (Crime and Disorder Act: 1998）以降、実際の犯罪だけでなく犯罪不安（fear of crime）もQOL上の課題として捉えられている。わが国においても、 実際の犯罪の抑止と住民の犯罪不安の軽減の両方を防犯まちづくり の目標とする必要がある。

公園の防犯に関しては、平成 12 年 2 月 24 日に警察庁が「道路、 公園、駐車場及び公衆便所に係る防犯基準」を公表している。これ は環境整備による防犯を目指す防犯環境設計（CPTED）の考え方 を取り入れたものである。しかし、同年に公表された「共同住宅に 倸る防犯上の留意事項」については翌年に具体的手法等を示す設計 指針が出されたのに比べ、公園については具体化されておらず、住
宅と比べて公園の防犯対策は立ち遅れていると言える。

防犯環境設計の視点からみた公園の防犯について、小出 ${ }^{1}$ は、「市 民の監視性を向上させるには、公園に対し市民の関心を高める必要 が不可欠であり、市民が関心を持って監視できる空間にするために は、利用者である市民や周辺住民の積極的な参加が必須となる。（中 略）特に管理において積極的な市民の協力が望まれる」と指摘して いる。また、平成 15 年 7 月 24 日に防犯まちづくり関係省庁協議会 がまとめた「防犯まちづくりの推進について」でも、防犯まちづく りの視点から「公共施設管理についてボランティア活動等を推進」 するとされている注2。このような住民による公園の管理活動は、ま ちづくりへの参加要請の高まり、自治体の財政難などを背景に、近 年増加傾向にあり、特に自然環境の少ない都市部においては住民の 参加ニーズが高い地域活動である。

本研究は、公園利用時の犯罪不安に影響する要因が住民による管 理活動によってどう改善されるか、またそれらの要因が犯罪不安に 繫がる構造を分析し、防犯まちづくりの視点から住民による公園管 理活動の評価・展望を行うことを目的とする。この研究によって、 公園管理への住民参加が推進され、安全に安心して利用できる公園 づくりが普及することが最終的なねらいである。ただし、本研究で は住民の生活に身近な街区公園レベルの規模を対象とし、以下単に

\footnotetext{
* 独立行政法人建築研究所住宅・都市研究グループ 研究員・ I博

** 東京大学工学部都市工学科 教授 $\cdot$ 工博
}

Researcher, Building Research Institute, Dr. Eng.

Prof., Faculty of Engineering, Tokyo Univ., Dr. Eng. 
「公園」と表現する場合はその規模の公園を意味することとする。

\section{1-2 既存研究}

雨宮 2) によれば、海外では「住民が公園緑地（の管理）に主体 的に関わることが、公園緑地に対する住民の領域意識を生み、結果 として『安全・安心』につながる」とされていることが報告されて いるものの、国内で住民による公園管理と防犯との関連を明らかに する研究は見られない。以下、本研究の関連研究を整理する。

住民による公園管理に関する既存研究は多く、街区公園、児童公 園を対象とする研究に限定すると、公園管理団体の実態把握を行っ たもの ${ }^{3 \sim 5}$ 、整備段階からの住民参加とその後の管理活動との関係 を探ったもの 6) などがある。また井上ほか 7) は、東京都区部の 11 公園を対象に、行政による管理実態、公園が抱える問題点、住民の 要望を踏まえ、住民による公園管理の計画的課題を明らかにしてい る。これらの研究では、住民活動によって管理水淮が向上する、問 題への対応が迅速に行われるなどの効果が明らかにされているが、 多くの公園が抱える課題である防犯との関係には触れていない。

公園の防犯に関する既存研究として、上杉ほか8）は、アンケート 結果の AHP (階層分析法) による分析を通じて、犯罪不安感が公園 の選択要因の一つであることを示しているが、不安感を誘発する具 体的要因までは明確に示していない。中村 ${ }^{9)}$ は、公園の安全確保に 向けて住民から出された要望を、「配置・レイアウト」、「植栽・樹木 管理」、「公園の管理」に分けて整理している。雨宮 ${ }^{10)}$ は、アンケ 一ト調査によって公園・緑道における住民の犯罪不安の発生状況を 罪種別に明らかにし、犯罪不安の発生要因を個人属性と公園・緑道 の特徵から明らかにしている。

住民の公園に対する評価に関する既存研究として、塚田ほか 11) は 36 項目の評価項目から因子分析により 10 の評価軸を抽出し、「利 用マナー」や「治安の良さ」が利用者の満足度に影響することを明 らかにしているが、それらの具体的要因にまでは踏み込んでいない。

本研究は、具体的な公園利用時の犯罪不安の要因を公園行政に対 する苦情の中から抽出し、それらの要因について特定の公園におけ る周辺住民の評価を分析し、住民による管理活動による各要因の改 善効果、そして各要因が犯罪不安に繋がる構造を明らかにする点で 特徴的である。

\section{1-3 研究の方法}

本研究は、住民参加による公園づくりの観点から、区と住民グル ープ（以下、里親グループ）がそれぞれの役割分担を決めた協定を 結ぶ「里親制度」がある一方で、近年の街頭犯罪の急增によって住 民の不安が高まっている東京都板橋区を対象地域とした。

まず、自治体担当課、警察、里親グループヘのヒアリング、区内 公園の現地調查、里親活動への参加等により、里親制度の運用状況 を把握し、本研究の対象とする里親公園を選定した。次に、板橋区 に寄せられる公園行政に関する意見・苦情等（以下、苦情）を分析 し、犯罪不安を誘発しうる項目を抽出した。そして、里親公園周辺 住民を対象とするアンケート調査によって、里親公園、非里親公園 の別にこれらの項目に対する評価等を聞き、その結果について分 析・考察を行った。

\section{2 里親制度 · 対象公園の概要}

\section{2-1 板橋区公園里親制度}

板橋区では、平成 16 年 7 月現在、17 公園で里親制度の協定が結 ばれている。里親制度が生まれた背景には、それまで板橋区で公園 の清掃活動を行っていた公園愛護協力会が「長い間に労働報酬的な 性格の事業に変容してしまった注引」ことなどがある。里親グループ は自発的な無償ボランティアとして公園の清掃・除草などを行い、 グループによっては花壇の手入れなども行う。

里親制度の協定が結ばれると、区はグループ名を記載した看板 （写真 1）を設置し、里親グループの活動を支援するための活動費 を助成する。必要に応じて管理倉庫を設置する場合もある。里親グ ループは週 1 回注4)の清掃・除草を基本とし、簡易な苦情への対応、 適正な公園利用の指導などを行う。施設の補修、剪定や病害虫駆除、 重要な陳情・苦情への対态は、他の公園と同様に区が行う。

\section{2-2 対象公園}

里親公園の中でも比較的規模が大きく、活動の実績も長い「けや きの公園（写真 2,3）」と「三丁目青空公園（写真 4)」を調查対象に 選んだ。両公園の概要を表 1 に示す。両公園とも計画段階から周辺 住民が参加するワークショップ形式で造られた新設の公園であり、 里親グループは週 1 回の清掃活動を行っている。特にけやきの公園 は大まかな計画から実施計画、工事計画、そして整備後の管理まで がワークショップの中で話し合われたこともあって「他と比べて住 民の活動が盛ん」(区みどりと公園課)であり、里親グループは従来 の活動に加えて、ハーブティのつどい、防災体験大会、コンサート、 もちつきなどのイベントも実施している。また、里親グループとは 別に「花作りグループさくらの会」が花增の維持活動を行っている。
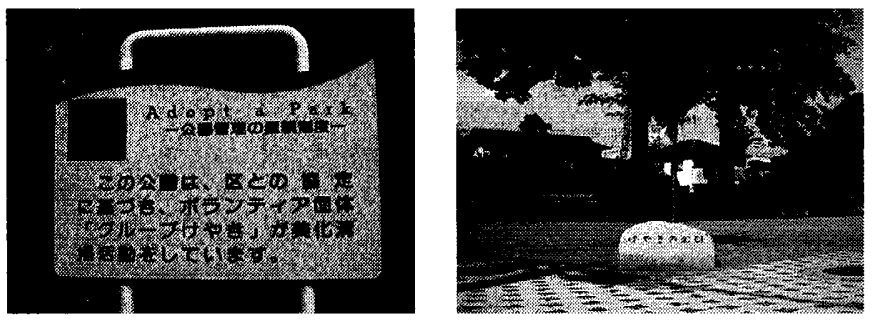

写真 1 里親公園の表示

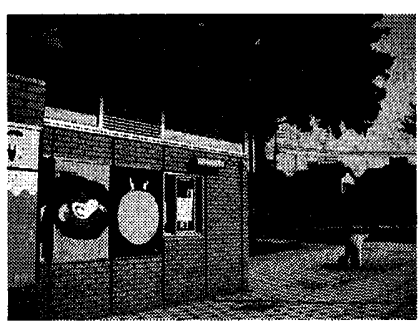

写真 2 けやきの公園

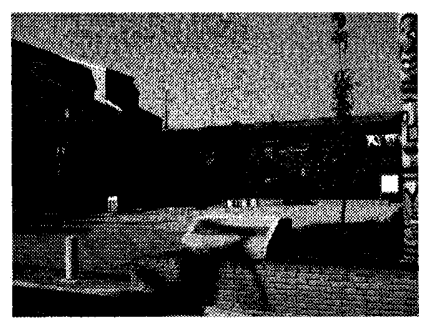

写真 3 けやきの公園ト化・倉庫

写真 4 三丁目青空公園

\begin{tabular}{|c|c|c|}
\hline & けやきの公園 & 三丁目青空公園 \\
\hline 所有 & 板橋区 & 板橋区 \\
\hline 面積 & $1,460 \mathrm{~m}^{2}$ & $905 \mathrm{~m}^{2}$ \\
\hline 整備完了日 & H12.3月 & H13.3月 \\
\hline ワータショップ 時期 (回数) & $\mathrm{H} 11.1 \sim 12.1$ 月（9 回） & $\mathrm{H} 12.1 \sim 3$ 月 (4回) \\
\hline ワークシ・ップ 参加者数 & 延 104 人 & 延 38 人 \\
\hline 所在地 & 前野町 1.48 & 小茂根 3-14 \\
\hline 用途地域 & 準工業地域 & 第一種中高層住居専用地域 \\
\hline 里親グループ & グループけやき & 青空公園里親の会 \\
\hline
\end{tabular}




\section{3 区に寄せられた苦情の分析}

\section{3-1 苦情の特徴}

板橋区に寄せられる公園行政に関する苦情は年閒 3000 件に及ぶ。 これらは公園の現状に対する利用者や周辺住民の改善要求であり、 公園の犯罪不安要因に関するヒントが含まれていると考えられる。 そこで、平成 14 年度内に板橋区みどりと公園課、および同南部公 園管理事務所に寄せられた苦情 1734 件をその内容によって分類し た注5)。分類数は区が行っている分類をもとに 11 分類とした。内訳 は、樹木に関する苦情（剪定、除草の希望など）が最も多く約 $1 / 3$ を占める。続いて、水回りに関する苦情（トイレの故障、蛇口の漏 水など）、施設・遊具に関する苦情（破損、落書など）が多い。これ を公園の規模別注6)に見ると、小規模な公園では、自転車・バイク、 中規模公園では、剪定、便所・排水、大規模公園では、ホームレス、 動物、利用の仕方に関する苦情が多い（表 2)。

\section{3-2 里親公園での苦情の特徵}

里親制度が導入されている公園は、同規模の他の公園と比べて苦 情の件数が多い。しかし、具体例としてけやきの公園に関して等せ られた苦情（8件）の内容を見ると、「犬の連れ込みを禁止する看板 をつけて欲しい、「水飲みのハンドルが壊れているので至急直して 欲しい」など、里親グループでは解決できない問題への対処を求め るものが全てだった。グループメンバーへのインタビューでも、「近 隣住民の要望はできる限り里親グループで解決を図り、自分たちで できないことを区に求める」という声が聞かれた。また、犬の連れ 込み問題に対しては、区に看板の設置を要望するだけでなく里親グ ループで連帯して注意を呼びかけるように取り決めた結果、現在で はグループメンバーだけでなく小学生など多くの地域住民が、犬を 連れ込んでしまった者に注意するようになっている。

このように、里親公園で苦情が多いのはむしろ住民の関心の高さ
を示すものと考えられ、けやきの公園の具体例からは、行政と住民 とがそれぞれの役割を担い、問題に対して迅速な対応がとられてい ることが分かった注7。

\section{3-3 犯罪不安を誘発しうる項目の抽出}

苦情のうち、犯罪不安を誘発しうるもの、犯罪や迷惑行為に該当 するものを、11 の分類別に抽出した。軽微な秩序違反であっても、 放置されればより深刻な犯罪、さらには地域の荒廃につながるとい う『割れ空理論（Broken Windows Theory）』の考え方に則り、軽 微な迷惑行為であっても犯罪不安を誘発しうる項目に含めた。樹木 が茂って見通しが悪いなど監視性の欠如を指摘するもの、器物損壊、 落書きなどのバンダリズムを指摘するもの、自転車等の放置、廃棄 物の不法投棄を指摘寸るもの、青少年のたむろ、ホームレスの占拠 を指摘するものが多い（表 2 )。

\section{4 アンケート調査の実施}

\section{4-1 調查概要と回答者の属性}

住民による公園管理が公園利用時の不安感に与える影響を把握 すべく、けやきの公園と三丁目青空公園のそれぞれの周辺住民に対 してアンケート調查を行った。調査の概要と回答者の属性をそれぞ れ表 3、表 4 に示す。

まず、里親公園周辺で最もよく利用する非里親公園を 1 つ選んで もらい注8)、表 5 に示す 18 項目について、里親公園及び選択した非 里親公園についてそれぞれ当てはまるか否かを5 段階で回答しても らった。項目 1〜16 3-3 で苦情から抽出した犯罪不安を誘発しう る項目を整理したものである注9)。さらに、里親制度の目的に照らし て「手入れが行き届いている小、利用者が多い」の2 項目を、それ ぞれ項目 17,18 として別途付け加えた注10（以下この18 項目を犯罪 不安関連項目と呼ぶ)。 5 段階の評価を -2 点（当てはまる）から 2

表 2 苦情の分類と犯罪を諉発しうる項目の抽出

\begin{tabular}{|c|c|c|c|c|c|c|c|c|}
\hline \multirow[b]{2}{*}{ 分類 } & \multirow[b]{2}{*}{ 件数 } & \multicolumn{5}{|c|}{ 規模別 } & \multicolumn{2}{|r|}{ うち犯罪不安を誘発しうるもの、犯罪や迷惑行為に該当するもの（件数・具体例） } \\
\hline & & $\begin{array}{r}\sim 433 \mathrm{~m}^{2} \\
64 \text { 公園 }\end{array}$ & $\begin{array}{l}.730 \mathrm{~m}^{2} \\
64 \text { 公園 }\end{array}$ & $\begin{array}{l}1360 \mathrm{~m}^{2} \\
65 \text { 公䔔 }\end{array}$ & . $2510 \mathrm{~m}^{2}$ & $\begin{array}{l}2511 \mathrm{~m}^{2} \\
64 \text { 公園 }\end{array}$ & $\begin{array}{l}\text { 件 } \\
\text { 数 }\end{array}$ & 具体例 \\
\hline 樹木 & 579 & 21 & 42 & 64 & 62 & 100 & 19 & 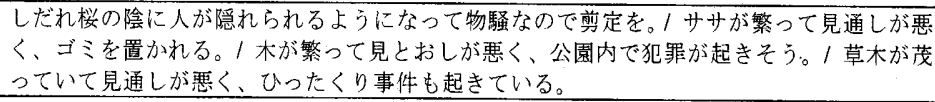 \\
\hline 水回り & 192 & 10 & 21 & 44 & 23 & 42 & 7 & $\begin{array}{l}\text { 蛇口が壊されて手洗いの水が出っぱなし。/トイレの覀が壊されている。/トイレのタンク } \\
\text { に悪戲されて漏水している。 } \\
\end{array}$ \\
\hline 時計·公園灯 & 123 & 5 & 15 & 20 & 20 & 40 & 1 & 周辺暗く痴漢出る。街灯を明るくして欲しい。 \\
\hline 施設 - 遊具 & 187 & 9 & 18 & 24 & 28 & 70 & 24 & 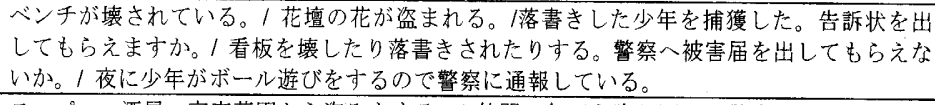 \\
\hline ホームレス & 68 & 2 & 3 & 14 & 3 & 31 & 14 & 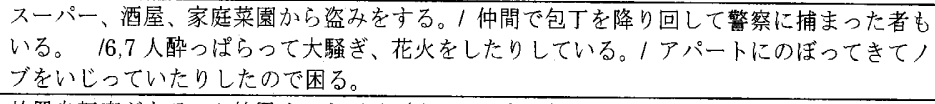 \\
\hline 自転車・バ仍 & 85 & 4 & 24 & 20 & 8 & 14 & 64 & $\begin{array}{l}\text { 放置自転車がある。/放置オートバイ (ナンバー無し) がある。/トラックがー週間以上放 } \\
\text { 县されている。 }\end{array}$ \\
\hline 害虫・蜂 & 88 & 1 & 6 & 8 & 9 & 12 & 0 & \\
\hline 動物 & 72 & 4 & 9 & 2 & 7 & 40 & 6 & 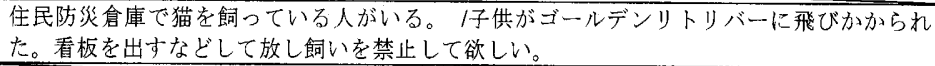 \\
\hline 鳥 & 77 & 3 & 12 & 8 & 10 & 22 & 0 & \\
\hline ゴミ・・清掃 & 126 & 5 & 19 & 18 & 15 & 37 & 56 & 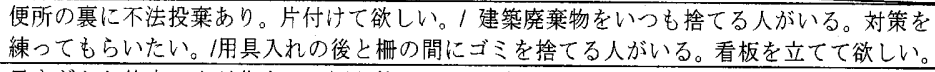 \\
\hline 利用の仕方 & 94 & 3 & 4 & 16 & 10 & 48 & 33 & 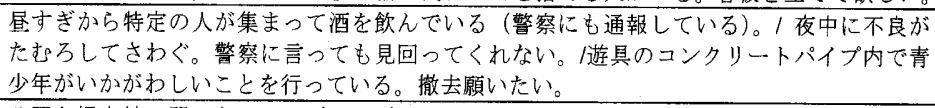 \\
\hline 分類不可 & 63 & 2 & 1 & 0 & 1 & 3 & 22 & 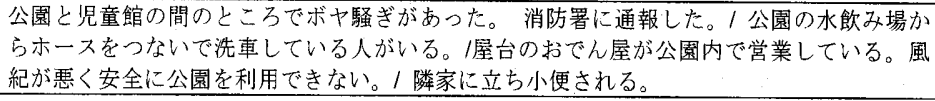 \\
\hline 合計 & 1734 & 69 & 174 & 238 & 196 & 459 & 246 & \\
\hline
\end{tabular}


表 3 アンヶート調查概要

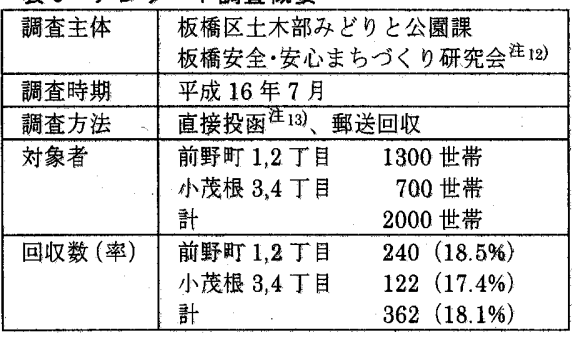

表 4 回答者の属性

\begin{tabular}{|c|c|c|c|c|}
\hline & 前野町 & 小茂根 & 全体 \\
\hline \multirow{3}{*}{$\begin{array}{l}\text { 性 } \\
\text { 別 }\end{array}$} & 男性 & 73 & 40 & 113 \\
\hline & 女性 & 142 & 73 & 215 \\
\hline & 無回答 & 25 & 9 & 34 \\
\hline \multirow{7}{*}{$\begin{array}{l}\text { 年 } \\
\text { 齢 }\end{array}$} & 20 代 & 18 & 6 & 24 \\
\hline & 30 代 & 52 & 29 & 81 \\
\hline & 40 代 & 36 & 20 & 56 \\
\hline & 50 代 & 57 & 24 & 81 \\
\hline & 60 代 & 38 & 21 & 59 \\
\hline & $70 \sim$ & 26 & 17 & 43 \\
\hline & 無回答 & 13 & 5 & 18 \\
\hline \multirow{6}{*}{$\begin{array}{l}\text { 世 } \\
\text { 帯 } \\
\text { 人 } \\
\text { 数 }\end{array}$} & 1 人 & 38 & 9 & 47 \\
\hline & 2 人 & 61 & 39 & 100 \\
\hline & 3 人 & 57 & 35 & 92 \\
\hline & $4 A$ & 48 & 27 & 75 \\
\hline & 5 人 & 28 & 11 & 39 \\
\hline & 無回答 & 8 & 1 & 9 \\
\hline \multirow{5}{*}{$\begin{array}{l}\text { 居 } \\
\text { 住 } \\
\text { 歴 }\end{array}$} & $\sim 1$ 年 & 10 & 5 & 15 \\
\hline & $1 \sim 5$ 年 & 63 & 26 & 89 \\
\hline & $5 \sim 10$ 年 & 47 & 26 & 73 \\
\hline & 10 年 & 117 & 63 & 180 \\
\hline & 無回答 & 3 & 2 & 5 \\
\hline \multirow{5}{*}{$\begin{array}{l}\text { 居 } \\
\text { 住 } \\
\text { 形 } \\
\text { 態 }\end{array}$} & 持家(戸建) & 66 & 48 & 114 \\
\hline & 持家(集合) & 111 & 33 & 144 \\
\hline & 借家(戸建) & 7 & 6 & 13 \\
\hline & 借家(集合) & 52 & 31 & 83 \\
\hline & 無回答 & 4 & 4 & 8 \\
\hline
\end{tabular}

点（当てはまらない） の得点とし 注11)、里親 公園と非里親公園の別、 また各里親公園別に、 回答者全員の平均点を 比較した。

\section{4-2 犯罪不安関連項 目の倸価}

18 項目の平均点に ついて里親公園と非里 親公園を比較 ( $\mathrm{T}$ 検定) した結果、表 5 に示す とおり、18 項目中 15 項目で有意な差が見ら れた（有意水準=0.1）。 特に、項目 $1,3,7,17$ に おいて、里親公園が非 里親公園より 1 点以上 高得点だった。項目 $1,7,17$ についは、里 親グループが自ら公園 の清掃や手入れを行い、 グループでできない部 分も区に要望するなど して対心した結果と考 えられる。項目 3 につ いては、里親活動によ

り公園の領域性注14）が確保された結果、あるいは電灯が切れた場合 も早期に発見して対応を求めた結果と考えられる。項目 2 で里親公 園の得点が低いのは、両里親公園に花壇があるのに対し、多くの非 里親公園には花壇がないためと考えられる。

また、両里親公園を比較すると、すべての項目でけやきの公園が 高得点であり、特に項目 7,8,18の差が大きかった。これらは、けや きの公園の里親グループが区内で最も活発であると言われる所以が 数字として表れたものと考えられる。

\section{4-3 公園利用時の「安心感」}

里親公園と非里親公園のそれぞれについて安心して利用できる か（以下、「安心感」）も5段階で質問した（図 1)。これを先の 18 項目と同様に -2 点 (不安) から 2 点（安心）の得点とした。18 項 目に「里親公園であることを知っているか、（知っている=1点、知 らない・里親公園でない $=0$ 点）を加えた 19 項目の平均点と「安心 感」との関係を調べるため一元配置分散分析を行った。サンプル数 は 471 である注15)。分析の結果、項目 2 以外で有意な差が見られ、 全項目でおおむ水「安心感」の水準が高いほど高得点になった。

\section{5 . 分析 · 考察}

\section{5-1 探索的因子分析}

共分散構造分析に先立ち、表 6 のうち「安心感」に有意な影響が 見られなかった項目 2 を除く 18 項目について探索的因子分析（最 尤法、プロマックス法) を行った結果を表 7 に示す。なお分析の過
表 5 犯罪不安関連項目に対する評価（里親公園と非里親公園の比較）

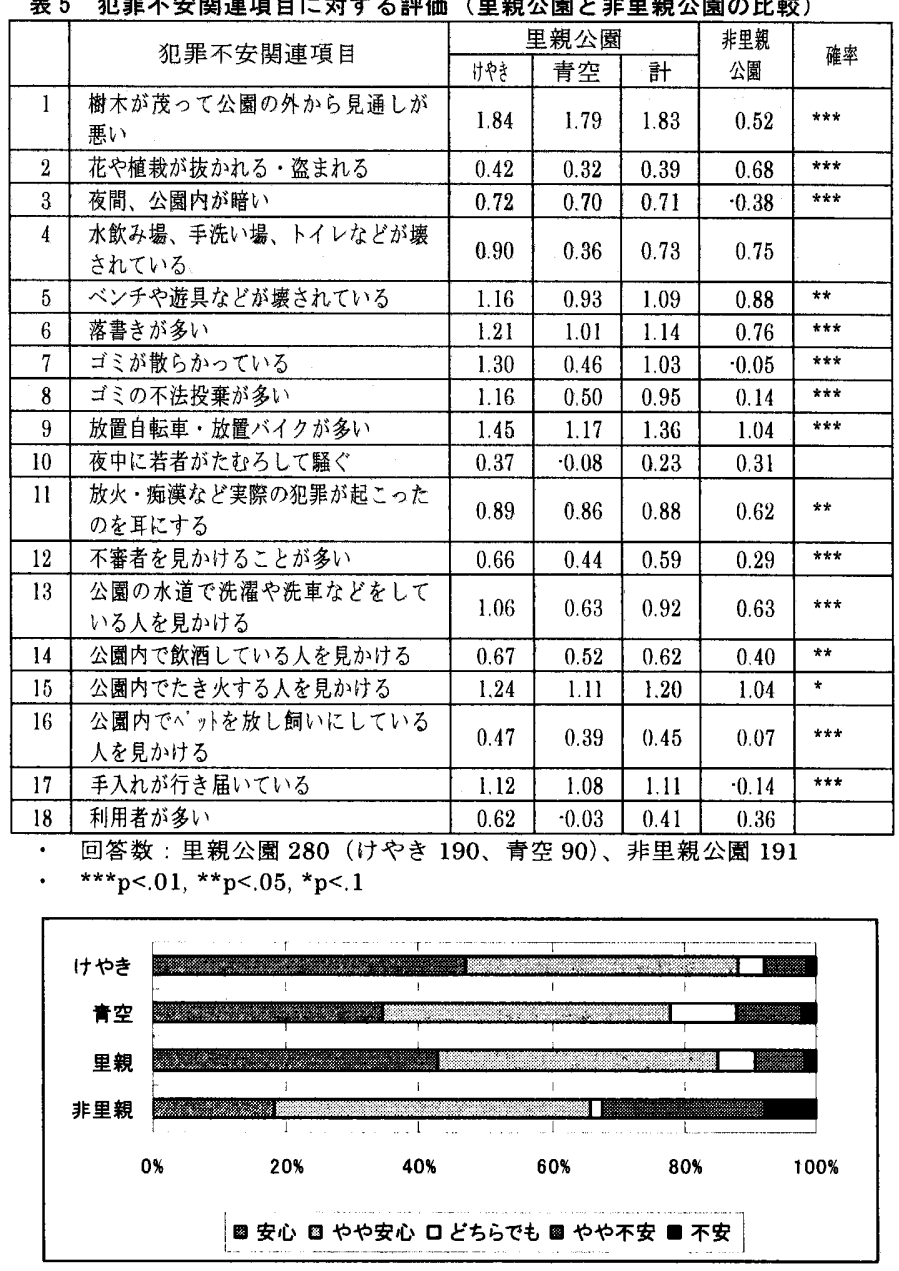

図 1 公園利用時の「安心感」(里親公園と非里親公團の比較)

表 6 犯罪不安関連項目と「安心感」との関係

\begin{tabular}{|l|r|r|r|r|r|r|l|}
\hline & 安心 & やや安心 & どちらでも & やや不安 & \multicolumn{1}{c|}{ 不安 } & 合計 & 確率 \\
\hline 項目 1 & 1.79 & 1.35 & 1.58 & 0.43 & -0.45 & 1.30 & $* * *$ \\
\hline 項目 2 & 0.57 & 0.50 & 0.16 & 0.49 & 0.40 & 0.50 & \\
\hline 項目 3 & 0.91 & 0.22 & 0.32 & -0.53 & -1.45 & 0.27 & $* * *$ \\
\hline 項目 4 & 1.05 & 0.70 & 0.32 & 0.43 & 0.10 & 0.74 & $* * *$ \\
\hline 項目 5 & 1.40 & 0.97 & 0.58 & 0.50 & 0.40 & 1.00 & $* * *$ \\
\hline 項目 6 & 1.48 & 0.93 & 0.58 & 0.31 & 0.40 & 0.99 & $* * *$ \\
\hline 項目 7 & 1.09 & 0.67 & 0.58 & -0.24 & -1.25 & 0.59 & $* * *$ \\
\hline 項目 8 & 1.11 & 0.66 & 0.05 & -0.06 & -0.75 & 0.62 & $* * *$ \\
\hline 項目 9 & 1.60 & 1.27 & 0.68 & 0.72 & 0.15 & 1.23 & $* * *$ \\
\hline 項目 10 & 0.55 & 0.22 & 0.05 & -0.09 & -0.25 & 0.26 & $* * *$ \\
\hline 項目 11 & 1.17 & 0.70 & 0.63 & 0.35 & 0.05 & 0.77 & $* * *$ \\
\hline 項目 12 & 0.83 & 0.52 & 0.68 & -0.18 & -0.85 & 0.47 & $* * *$ \\
\hline 項目 13 & 1.08 & 0.86 & 0.53 & 0.29 & 0.10 & 0.80 & $* * *$ \\
\hline 項目 14 & 0.88 & 0.56 & 0.16 & 0.04 & -0.45 & 0.53 & $* * *$ \\
\hline 項目 15 & 1.42 & 1.15 & 0.58 & 0.71 & 0.70 & 1.13 & $* * *$ \\
\hline 項目 16 & 0.48 & 0.33 & 0.26 & -0.07 & -0.35 & 0.29 & $* * *$ \\
\hline 項目 17 & 1.19 & 0.65 & 0.79 & -0.44 & -1.05 & 0.60 & $* * *$ \\
\hline 項目 18 & 0.65 & 0.40 & 0.11 & 0.12 & -0.60 & 0.39 & $* * *$ \\
\hline 里親認知 & 0.50 & 0.23 & 0.26 & 0.03 & 0.15 & 0.29 & $* * *$ \\
\hline
\end{tabular}

${ }^{* * *} p<.01,{ }^{* *} p<.05,{ }^{*} p<.1$

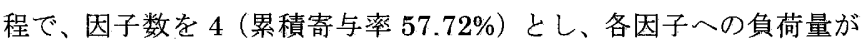
小さかった項目 16 を削除した（最大 0.276）。因子分析の下位尺度 の信頼性を検討するため、各因子について 0.3 以上の負荷量を示し た項目を尺度として $\alpha$ 係数を算出したところ、因子 $1,2,4$ では 0.8 前後の高い值をとり、因子 3 でもまずまずの值 $(0.607)$ であった。 まず、因子 2 に高い負荷量を示した項目は、設備が壊されたり落 
書きされたりというものであることから、因子名を「破壊行為（バ ンダリズム)の痕跡」とした。因子 4 に高い負荷量を示した項目岋、 ゴミや放置自転車に関するものであることから、因子名を「ゴミの 散乱・不法投棄」とした。ここで、因子 1 に高い負荷量を示した項 目は、(因子 2,3 の項目以外の) 望ましくない行為や人物の見聞経験 に関するものであることから、因子名を「望ましくない人物・行為 の見聞」とした。最後に、因子 3 に高い負荷量を示した項目のうち、 項目 1,3 は防犯環境設計（CPTED）における「監視性の確保」に関 する項目で、その他は「領域性の確保」に関する項目であることか ら、因子名を「領域性・監視性の確保」とした。

因子分析の結果を見て、各因子の上位 4 位以内かつ因子負荷量の 絶対值が 0.4 以上という条件を満たす 13 項目を観測変数として扱 うこととした。

\section{5-2 モデルの作成}

5-1で選んだ 13 項目と「安心感」を観測変数とし、抽出した 4 因 子（望ましくない人物・行為の見聞、破壊行為の痕跡、領域性・監 視性の確保、ヨ゙ミの散乱・不法投亲）を潜在変数とするモデルを作 成した（図 2)。モデル作成に当たり、4つの潜在変数と「安心感」 には次のような関係があると考えた。

- 表 6 に示した各要因と「安心感」との関係から、4つの潜在変 数は全て「安心感」に影響する。

- 防犯環境設計 (CPTED) の「領域性・監視性」が確保される ことにより、「ゴミ」の投萧、「破壊行為」「望ましくない行為」 を実行しづらい環境が生まれ、これらの行為に対する抑止効果 が生まれる。ただし、ゴミの存在が管理されていないという印 象を生み領域性が損なわれることから、「ゴミ」と「領域性・ 監視性」の間は双方向の関係とする。

・軽微な秩序違反も放置されればエスカレートするという『割れ 空理論』によれば、「ゴミ」が投㕕されたままであれば、より 高次の迷惑行為である「破壊行為」を生む結果となる。

・「ゴミ、「破壊行為」によって環境が悪化した状態が続けば、 「望ましくない人物や行為」を招く結果となる。

\section{5-3 分析. 考察}

5-2 のモデルを共分散構造分析にかけた。途中、相関係数が $1 \%$ 有 意を満たさなかったパスを逐次削除し、図 3 の分析結果を得た（数 值は標準化解)。

この分析結果を見ると、公園の有する「領域性・監視性」が利用 時の安心感に大きく寄与する（パス係数：0.64）一方、安心感が損 なわれる理由としては、施設への「破壊行為の痕跡」が若干影響す る(0.12) だけで、他の潜在変数の直接の影響は小さい。「領域性・ 監視性」は園内の「ゴミの散乱・不法投棄」と共変関係にあり $(0.63) 、$ 領域性や監視性の確保によってゴミを捨てにくい状況が生まれる一 方で、ゴミのない手入れの行き届いた環境が領域性に奇与するとい ら双方向の関係にあると考えられる。また「領域性・監視性」は「望 ましくない人物・行為の見聞」も抑える方向に影響する $(0.20)$ 为、 「破壊行為」への影響は比較的小さい(0.10)。これは人目の及ばな い夜間に破壊行為が行われるためと考えられる。

ここで「ゴミの散乱・不法投棄」、「破壊行為の痕跡」、「望ましく ない人物・行為の見聞」の 3 つの潜在変数の関係を見ると、「ヨミ」、

「破壊行為」は「望ましくない人物・行為」に影響し、特に後者の
影響が大きい(0.50)。また「ゴミ」は「破壊行為」にも影響する(0.56) ことから、散乱した、あるいは不法投棄されたゴミが放置されてい ると破壊行為が行われるようになり、さらには望ましくない人物や 行為が見聞されるようになるという環境悪化の流れが見出される。

表 8 には主な適合度指標の値を示した。このカイ 2 乗検定の結果 だけを見るとモデルは棄却されてしまうが、他の指標がまずまずの 值であることから、妥当性を備えたモデルと言える注16)。

\begin{tabular}{|c|c|c|c|c|}
\hline & 因子 1 & 因子 2 & 因子 3 & 因子 4 \\
\hline 寄与率 & $31.68 \%$ & $10.36 \%$ & $6.95 \%$ & $6.59 \%$ \\
\hline$\alpha$ 係数 & 0.796 & 0.778 & 0.607 & 0.813 \\
\hline 因子名 & $\begin{array}{c}\text { 望ましくない } \\
\text { 人物・行為の見聞 } \\
\end{array}$ & $\begin{array}{c}\text { 破壊行為 } \\
\text { の痕跡 } \\
\end{array}$ & $\begin{array}{c}\text { 領域性・監視性 } \\
\text { ()確保 } \\
\end{array}$ & $\begin{array}{l}\text { ゴミの散乱 } \\
\text { ・不法投棄 }\end{array}$ \\
\hline 項目 1 & 0.046 & 0.018 & 0.654 & 0.047 \\
\hline 項目 3 & 0.216 & $\cdot 0.066$ & 0.508 & -0.010 \\
\hline 項目 4 & 0.086 & 0.639 & -0.153 & 0.044 \\
\hline 項目 5 & -0.092 & 0.865 & 0.055 & -0.065 \\
\hline 項目 6 & 0.060 & 0.568 & 0.097 & 0.090 \\
\hline 項目 7 & 0.017 & 0.001 & 0.192 & 0.707 \\
\hline 項目 8 & 0.013 & 0.020 & $\cdot 0.008$ & 0.898 \\
\hline 項目 9 & 0.092 & 0.356 & 0.007 & 0.984 \\
\hline 項目 10 & 0.525 & 0.066 & 0.183 & 0.179 \\
\hline 項目 11 & 0.661 & 0.162 & 0.094 & -0.247 \\
\hline 項目 12 & 0.783 & -0.107 & 0.060 & -0.023 \\
\hline 項目 13 & 0.476 & -0.030 & $\cdot 0.017$ & 0.209 \\
\hline 項目 14 & 0.672 & -0.094 & $\cdot 0.089$ & 0.130 \\
\hline 項目 15 & 0.488 & 0.192 & 0.023 & -0.056 \\
\hline 項目 17 & -0.090 & -0.034 & 0.656 & 0.084 \\
\hline 項目 18 & -0.215 & 0.007 & 0.889 & 0.073 \\
\hline 里親認知 & 0.058 & 0.040 & 0.469 & -0.060 \\
\hline
\end{tabular}

因子抽出法：最尤法、回転法：Kaiser の正規化を伴うプロマックス法 網掛けは 0.3 以上

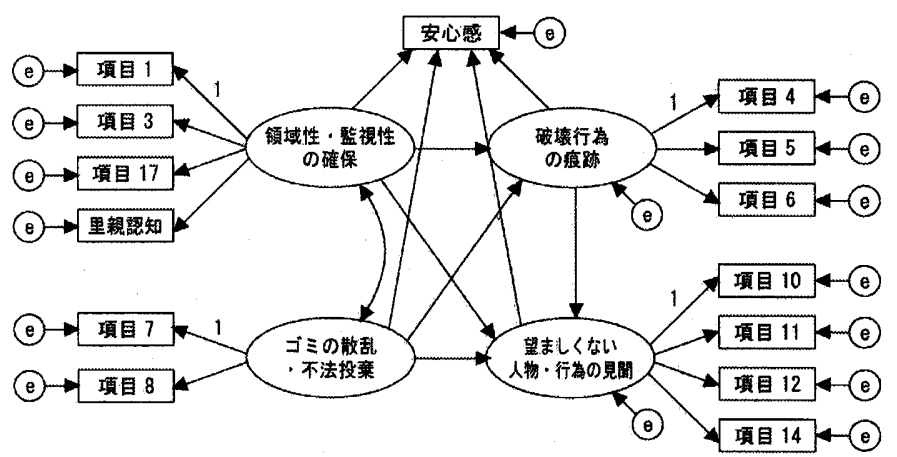

図 2 公園利用時の不安関連項目に関する因果モデル

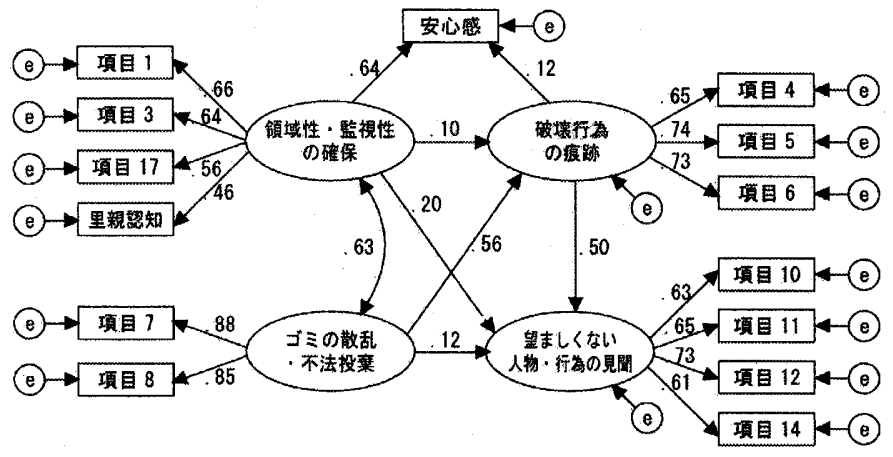

図 3 共分散構造分析の結果（標準化解）

\section{表 8 共分散構造分析の結果（適合度指標）}

\begin{tabular}{|c|c|c|c|c|c|}
\hline \multicolumn{3}{|c|}{ 力イ 2 乗検定 } & \multirow{2}{*}{ GFI } & \multirow{2}{*}{ AGFI } & \multirow{2}{*}{ RMSEA } \\
\hline カイ 2 乗值 & 自由度 & 確率 & & & \\
\hline 197.6 & 70 & .000 & .945 & .917 & .062 \\
\hline
\end{tabular}




\section{6. おわりに}

本研究では、公園に関する苦情等から抽出した犯罪不安関連項目 が利用者の不安感に繫がる構造を明らかにし、住民による管理活動 がその改善に貢献することを明らかにした。本研究で得られた主な 知見は以下の通りである。

- 公園に関する苦情等から抽出した 18 項目の犯罪不安関連項目 のうち、14 項目について里親公園のほうが有意に高得点だっ た。また、里親公園では、公園の問題について、区に要求する だけでなく、住民で解決しようという動きが見られた。

・ けやきの公園と三丁目青空公園を比べると、18 項目全てにつ いて前者の方が高得点であり、里親公園同士でも犯罪不安関連 項目の水準には差が見られた。

- 公園利用時の安心感と 18 項目との関係を調べると、1 項目を 除いて有意な関係があり、抽出した犯罪不安関連項目が適切で あることが分かった。

・因子分析により、犯罪不安関連項目に影響する因子として、「望 ましくない人物・行為の見聞」、「破壊行為の痕跡」、「領域性・ 監視性の確保」、「ゴミの散乱・不法投棄」の 4 因子を抽出でき た。

- 共分散構造分析から、「領域性・監視性の確保」が公園利用時 の安心感に大きく寄与することが分かった。この因子は「ゴミ の散乱・不法投裹」と共変関係にあり、里親活動による領域性 の強化、公園の美化が利用者の安心に僖がっていると言える。 ゴミの放置は、破壊行為やその他の望ましくない行為など、よ り高次の迷惑行為に繫がることが分かった。

以上の知見を踏まえて考察する。

本研究の分析により、里親活動の中心である清掃・美化が領域性 の確保や破壊行為の抑止に繫がり、利用時の安心感を生んでいるこ とが明らかになった。一般的に経済的側面や参加者の生きがい推進 の面から評価されることが多い里親制度だが、防犯まちづくりの視 点からも評価されることで、既存の里親グループは活動の動機を強 め、行政は里親制度を推進する根拠を持ち得るだろう。

また利用者の観点からは、領域性・監視性の確保が安心感に大き く寄与することが示された。領域性強化の観点からは、看板による 里親の存在の明示に加え、イベントや花壇活動の推進、参加者募集 を兼ねた広報活動などが有効である。監視性強化の観点からは、樹 木の繁茂による見通しの悪化や公園灯の故障などが周辺住民によっ て早期に行政に伝えられるという協働関係が有効である。いずれも 本研究の調查対象であったけやきの公園では実行されており、他自 治体にとってもモデルケースとなり得るだろう。さらに提案するな ら、里親グループが普段の活動から防犯まちづくりの視点を意識す ることで犯罪不安の改善効果はさらに大きくなると考えられること から、里親グループに対して防犯まちづくりに関する講習会の実施 やパンフレット配布などの啓発活動を行うことが有効に働くだろう。

最後に今後の課題について述べる。今回のモデルで公園利用時の 不安感がすべて説明できたわけではなく、周辺の犯罪発生状況や土 地利用など、他の要因を考慮したモデルの改善が必要である。また 公園以外の公共施設についても住民による管理が有効に機能するか 検証が必要である。
本研究を進めるにあたって、板橋区土木部みどりと公園課にご協力いただき ました。また本研究は（財）社会安全財団の研究助成を受けて行っており 寸。ここに記して謝意を表します。

参考文献

1）小出治、「公園づくりにおける防犯環境設計」、公園緑地、vol60、no.6、 pp.13·15、公園緑地協会、 2000

2）雨宮護、「公園緑地を対象とした安全・安心をめぐる研究の系譜と計画 論八向けての展望」、ランドスケーブ研究、66(3)、pp.183·190、日本造 園学会、2003

3）根来千秋・渡辺達三、「児童公園等の管理における地域住民の参加・協 力に関する考察」、日本都市計画学会学術研究論文集、pp.271-276、1987 岩村高治・横張真、「神戸市における地域住民による公園管理の実態と その展望」、ランドスケープ研究、64(5)、pp.671·674、日本造園学会、 2001

5）天石直、「公園の管理運営段階における住民参加の実態と今後のあり方 〜東京 23 区の事例より」、東京大学大学院都市工学専攻 2001 年度修士 論文梗概集、2002

6）岩村高治・横張真、「公園計画策定時における住民参加がその後の公固 管理運営活動に与える影響」、ランドスケープ研究、65(5)、pp.735-738、 日本造園学会、2002

7）井上ちひろほか、「都市居住地における街区公園・児童公園の管理方法 に関する研究」日本建築学会計画系論文集、no.578、pp.9-15、2004

8）上杉知ほか、「犯罪不安感を考慮した住区基幹公園の利用選択に関する 研究」、日本都市計画学会学術研究論文集、pp.61·66、1999

9）中村攻、「都市公園と犯罪」、ランドスケープ研究、66(3)、pp.174·179、 日本造園学会、2003

10）雨宮護・横張真、「ニュータウン内の公園・緑道における犯罪不安発生 の実態」、都市住宅学、43 号、pp.18·23、都市住宅学会、2003

11）塚田伸也・湯沢昭、「住民意識から捉えた小公園の評価構造に関す万研 究」、日本都市計画学会学術研究論文集、pp.907-912、2002

12）大塚高雄、「けややきの公園」がもたらしたもの一板橋区前野町一丁目の 場合一」、都市公園、財団法人東京都公園協会 No.151、pp.63-82、2000

13）桶野公宏ほか、「公園に㧍ける犯罪不安要因に関寸る一考察」、都市計画 報告集、Vol. $2 \cdot 4 、$ pp.132-135、2004

14）G.L.ケリング・小宮信夫監訳、『割れ空理論による犯罪防止』、文化書房 博文社、2004

注

注1）「自分や身近な人が犯罪に遭うかもしれないと不安になる場所」は順に、 路上 $(53.9 \%) 、$ 慗華街 $(45.0 \%) 、$ 公園 $(33.9 \%)$ となっている。以降順に、 駐車場、駅、エレベーター、インターネット空間、自宅、電車や飛行機 などの乗り物の中、その他、特にないと続く

注2）「(4)防犯まちづくりに拈ける公共施設の整備・管理に係る留意事項」に 明記されている。

注3) 文献 $12 、$ p.77

注4）要季の水遗り海日行う。

注5）板橋区では、土木部みどりと公園課が公園行政を担っており、南部公園 事務所、北部公園事務所の 2 つの公園事務所が公園や緑地の維持管理を 行っている。こでは、デジタルデータ化されている、板橋区タどりと 公園課、および同南部公園管理事務所への苦情のみを扱った。

注6）板橋区内の区立公園（194 筬所）、巟童遊園（128 筒所）を面積順に並 ベ、数が均等になるように規模を5 段階に区分した。

注7）文献 7 でも同様の知見が得られている。

注8）けやきの公園周辺住民には前野町 $12.2 丁$ 丁目の 14 の非里親公圆から= 丁目青空公園周辺住民には小茂根 3,4 丁目 94 万の非里親公園加らよく 利用する公園を選んでもらった。地区公園など大規模なものは除いた。

注9）本調查の共同実施者である板橋区みどりと公園課の意向により、「樹木 の陰に人がひそんでいそう」、「ホームレスを見かけることが多い」の項 目は削除した。

注10) 文献 6 では地域住民による公園活動を維持管理活動（清掃等）と運営 管理活動 (イベント実施等) に区分しており、ここではそれぞれに対応 する項目として「手入れが行き届いている」、「利用者が多い」を付け加 えた。運営管理活動の目的は、公園に愛着を持たせ、利用を促進するこ とと解釈した。

注11）項目 $17 、 18$ は逆に-2 点（当てはまらない）加 2 点（当てはまる） とした。なお久損值は「どちらでもない」と同じく0点として扱った。

注12）板橋安全·安心まちづくり研究会は平成 15 年 6 月に設立した任意の研 究会であり、板橋区、警察、専門家、地域団体等で構成される。

注13）アンケート票はポスティング業者に委託し、指定した町丁目内の世帯 の5ち、対象となる公園に近い世帯から順次配布した。

注14）「領域性」について、例えば文献 14 で小宮信夫は「八ード面の区画性 とソフト面の縄張り意識から成る」と解釈しているが、本研究では各文 献を参考に、「適切な利用と管理によって外部に示される場のイメージリ の意で用いた。

注15）1人の回答者が 2 つの公園を評価するため $362 \times 2=724$ のサンプル数が 得られる計算になるが、1項目も評価しなかったサンプルは除いたため、 サンプル数は 471（けやき 190、青空 90、非里親公園 191）となった。

注16）本調查の上うにサンプル数が大きいと、カイ 2 乗検定でモデルが採択 されることは少ない。他の指標については、一般に次のような值をとれ ば当てはまりのいいモデルとされるが、これらを満たす、あるいは近い 值を示している。 GFI $>0.95 、 A G F I>0.9 、$ RMSEA $<0.05$ 